\title{
BMJ Global Heath Mitigating the impact of COVID-19 on children's surgery in Africa
}

To cite: Mazingi D, Ihediwa G, Ford K, et al. Mitigating the impact of COVID-19 on children's surgery in Africa. BMJ Global Health 2020;5:e003016. doi:10.1136/ bmjgh-2020-003016

$\mathrm{DM}, \mathrm{Gl}$ and $\mathrm{KF}$ are joint first authors.

Received 27 May 2020 Revised 29 May 2020 Accepted 2 June 2020

Check for updates

(c) Author(s) (or their employer(s)) 2020. Re-use permitted under CC BY. Published by BMJ.

${ }^{1}$ Department of Surgery, University of Zimbabwe College of Health Sciences, Harare, Zimbabwe

${ }^{2}$ Paediatric Surgery Unit, Department of Surgery, Lagos University Teaching Hospital, Surulere, Lagos, Nigeria ${ }^{3}$ Department of Specialist Neonatal And Paediatric Surgery, Great Ormond Street Hospital, London, UK

${ }^{4}$ Department of Population, Policy and Practice, Institute of Child Health, University College London, London, UK

${ }^{5}$ Department of Surgery, College of Medicine, University of Lagos, Lagos, Lagos, Nigeria

${ }^{6}$ Nuffield Department of Surgical Sciences, Oxford University Hospitals NHS Trust, Oxford, UK

Correspondence to Dr Dennis Mazingi; dennis.mazingi@gmail.com

\author{
Dennis Mazingi (D) , ${ }^{1}$ George Ihediwa, ${ }^{2}$ Kathryn Ford, ${ }^{3,4}$ Adesoji O Ademuyiwa, ${ }^{5}$ \\ Kokila Lakhoo ${ }^{6}$
}

\section{INTRODUCTION}

An outbreak of the disease known as COVID19 , which originated in Wuhan in the Hubei province of China, has rapidly spread to all continents of the globe. ${ }^{1}$ First detected via local hospital surveillance systems as a 'pneumonia of unknown aetiology' in late December $2019,{ }^{2}$ the disease has since been declared a public health emergency of international concern by the WHO and reached pandemic status.

It is uncertain what the eventual toll of the pandemic will be in Africa; however, there has been a suspicion that the looming pandemic may hit harder than it has the rest of the world. ${ }^{3}{ }^{4}$ Africa has baseline weaknesses in healthcare resource allocation, and her fragile healthcare systems are particularly vulnerable to being overwhelmed by this illness. ${ }^{56}$ Available statistics, to date, however, seem to show that the pandemic has been slow to begin. As of 26 May, 115346 cases and 3471 deaths have been reported across the whole African continent, constituting $2 \%$ of all cases in the globe. ${ }^{7}$ African nations have had an opportunity to prepare for the coming onslaught, learn from the experience in other countries ${ }^{3}$ and choose interventions that are tailor-made for the unique socioeconomic context. ${ }^{6}$

While old age has consistently been associated with a higher risk of poor outcome, children appear to have escaped the worst of the disease. ${ }^{8}$ In a recent series from the Chinese Center for Disease Control and Prevention, less than $1 \%$ of the 73314 cases were children below 10 years of age. ${ }^{9}$ Children of all ages may be affected, but they typically manifest mild or asymptomatic disease. ${ }^{1011}$ This has important implications for the African pandemic: sub-Saharan Africa is the youngest continent in the globe with $63 \%$ of its population below the age of 25 years. ${ }^{12}$ The demography of Africa appears to portend a favourable course through the pandemic; however, it is unknown how the high prevalence of HIV infection, tuberculosis, malnutrition and the scourge of poverty will affect the human impact of the disease. ${ }^{13}$

The COVID-19 pandemic has placed unprecedented strain on health services around the world, and paediatric surgical services are no exception. ${ }^{1415}$ Responses from surgical societies around the world thus far have focused on maintaining provision of emergency and urgent elective services while protecting healthcare workers (HCWs).$^{13} 16$ There is a risk of healthcare resources being diverted away from surgical care, potentially impeding progress towards global surgery goals for $2030 .{ }^{17}$ Paediatric surgical care may only be tangentially affected by this pandemic; however, there are unique considerations that deserve special attention. This article explores the wider implications for children's surgery in Africa, drawing lessons from the past and giving recommendations for the current pandemic and future (table 1).

\section{RATIONING OF SURGICAL SERVICES}

Non-essential surgical and non-surgical activities should be curtailed to provide surge capacity for the expected pandemic-related influx. This is consistent with guidelines from manysurgical societies worldwide ${ }^{1316}$; however, heavy-handed shutdown policies have been discouraged in the African context because they risk exacerbating the already formidable surgical disease burden with disastrous consequences. ${ }^{13} 18$ Elective surgical activity has been postponed in Zimbabwe, ${ }^{19}$ South Africa, ${ }^{20}$ Kenya $^{21}$ and Malawi, among many other countries. Negative effects should be anticipated if the past is anything to go by. During the 2003 severe acute respiratory syndrome-related coronavirus (SARS-CoV)-1 outbreak in Toronto, stringent restrictions on non-essential surgical services were thought to have aggravated precipitous declines in surgical volume, with only small increases in 
Table 1 Recommendations for paediatric surgery during the COVID-19 pandemic based on the domains identified including justification

\begin{tabular}{|c|c|c|}
\hline Domain & Recommendations & Justification \\
\hline Surgical provision & $\begin{array}{l}\text { Consider surgical approaches that minimise length of } \\
\text { hospital stay. }\end{array}$ & $\begin{array}{l}\text { To minimise the chance of nosocomial } \\
\text { spread }\end{array}$ \\
\hline HCW welfare & $\begin{array}{l}\text { HCW life insurance cover in the event of death or } \\
\text { incapacitation. }^{19} \\
\text { Psychological support. }{ }^{13} \\
\text { Frequent personal protective equipment training and } \\
\text { retraining. }\end{array}$ & To protect HCWs \\
\hline Guardian policy & $\begin{array}{l}\text { Designate a 'resident/in-hospital guardian' who lives on } \\
\text { hospital grounds and is isolated from outside visitors. } \\
\text { Limit in-hospital guardians to one person to prevent } \\
\text { overcrowding. } \\
\text { - Hand hygiene for in-hospital guardians. }{ }^{49}\end{array}$ & $\begin{array}{l}\text { To facilitate social distancing and } \\
\text { minimise the chance of nosocomial } \\
\text { spread }\end{array}$ \\
\hline Child protection & $\begin{array}{l}\text { Designate areas separate from general wards for children } \\
\text { who may require protection during the pandemic. } \\
\text { Strengthen social service structures during pandemics. }\end{array}$ & To protect children \\
\hline Training & $\begin{array}{l}\text { Training programmes to introduce virtual didactics. } \\
\text { Consider altering trainee minimum requirements in light of } \\
\text { declines in surgical volume and learning time. } \\
\text { Increased collaborative learning between training } \\
\text { programmes across borders. }\end{array}$ & $\begin{array}{l}\text { To minimise the disruption to paediatric } \\
\text { surgery workforce growth } \\
\text { To strengthen surgical training programs }\end{array}$ \\
\hline
\end{tabular}

HCW, healthcare worker.

surge capacity for the outbreak. ${ }^{22}$ Postpandemic waiting lists for paediatric cancer are also expected to be sizeable. ${ }^{4}$ A recent modelling study from the "COVIDSurg Collaborative' paints a grim picture. Twenty-eight million surgical operations are estimated to be cancelled and low-income and middle-income countries (LMICs) such as Africa will be hardest hit. ${ }^{23}$ The expectation that surgical volumes will bounce back rapidly is implausible, particularly in countries where there was already baseline fragility, and it may take longer than the 45 weeks forecast to make up the backlog. ${ }^{23}$ Current surgical rationing policies are based on a classification of the urgency of the patient's intervention, such as the National Confidential Enquiry into Patient Outcome and Death system. ${ }^{19} 24$

\section{EFFECTS ON SURGICAL PRACTICE}

Paediatric surgical services in Africa are characterised by significant delays in health-seeking and within the referral chain. ${ }^{25}$ The mobility restrictions imposed on patients by shelter-in-place measures, as well as reduced income during the pandemic, will presumably cause further delays in presentation that may adversely affect outcomes.

The change to non-operative treatment in eligible patients for certain conditions, for example, appendicitis that is being contemplated, may find less success in Africa, where a higher proportion of patients have complicated disease not amenable to non-operative treatment. ${ }^{26} \mathrm{It}$ also has the potential to prolong hospital stay, ${ }^{27}$ which increases the chances of nosocomial transmission of the virus.

\section{PREOPERATIVE SCREENING AND TESTING}

Perinatal transmission of SARS-CoV-2 has not yet been demonstrated in recent small case series and a systematic review. ${ }^{28-30}$ This is consistent with findings during the SARS-CoV- $1^{31}$ and Middle East respiratory syndrome (MERS-CoV) epidemics ${ }^{32}$ and should reassure surgeons working with neonates. However, neonates can still acquire infection from an infected mother's respiratory secretions. ${ }^{33}$ Also, $\mathrm{Xu}$ et al reported on eight infants who tested positive on rectal swabs even after having tested negative by nasopharyngeal swabs. ${ }^{34}$ This was thought to potentially represent faeco-oral viral transmission and has implications for surgeons of the gastrointestinal tract. SARS-CoV-2 has also been isolated in peritoneal fluid. ${ }^{35}$ Larger studies are needed to determine the significance of these findings. Airborne and contact precautions are indicated in all HCWs working with children of all ages. 


\section{HEALTHCARE WORKERS}

Experience from previous pandemics has demonstrated that HCWs are the lynchpin of resilient surgical systems during an outbreak. During the Ebola outbreak, the unfortunate death of $25 \%$ of the surgeons in one institution has led to a $97 \%$ reduction in surgical volumes, ${ }^{36}$ while trepidation on the part of HCWs and lack of personal protective equipment have led to a reluctance to work during the SARS-CoV-1, ${ }^{37}$ MERS-CoV ${ }^{38}$ and Ebola ${ }^{39}$ outbreaks. This is particularly damaging in Africa, where HCW morale is already low. ${ }^{40} \mathrm{HCW}$ should be first in the minds of policy-makers because the axiom that there is no health without a workforce is as true during a pandemic as it is at any other time. ${ }^{41}$

Children have been called 'the link in the transmission chain' because of their importance in facilitating and amplifying viral transmission. ${ }^{42}$ Paediatric care in Africa is typically characterised by significant involvement by guardians and other family members who support the child during hospital admission, assist the overburdened healthcare workforce and act as care advocates. ${ }^{434}$ They frequently live on the hospital grounds because of long distances from home and prohibitive transportation costs. ${ }^{43}$ A study from Malawi showed that overcrowding in the hospital was a major issue due to the large population of guardians in the hospital. ${ }^{45}$ This is at odds with social distancing policies and has the potential to accelerate nosocomial transmission. Guardians should be limited to the minimum practical number per patient (table 1). Guardian policy should also take into account 'parental presence at induction of anaesthesia', a common practice that facilitates administration of anaesthesia but potentially places the parent at risk during an aerosolgenerating procedure.

Hospital visitors have been implicated as vectors in pathogen transmission during the SARS-CoV-1 outbreak of 2002-2004, ${ }^{4647}$ and hospital visitor policies were changed accordingly. ${ }^{48}$ The evidence linking restrictive visiting policies with prevention of nosocomial transmission during outbreaks is scant; however, it is a rational approach until better evidence comes to light. Expert guidelines from the Society for Healthcare Epidemiology of America give recommendations for guardian and visitor policy based on a systematic review of the literature and are incorporated in our recommendations ${ }^{49}$ (table 1).

\section{CHILD PROTECTION DURING PANDEMICS}

Experiences from this and past epidemics show that in health emergencies children, the most vulnerable members of society suffer disproportionately. ${ }^{505152}$ The 'Agenda for Action' recently announced by UNICEF is a timely intervention aimed at preventing the pandemic from becoming a child's-rights crisis.

The incidence of family violence ${ }^{53}$ and accidental household trauma, for example, burn injuries, are anticipated to rise during the pandemic and is associated with shelter-in-place measures. ${ }^{54}$ Paediatric surgeons have a unique role in management of the traumatic injuries, protection of children from a dangerous household and in tertiary prevention (minimising the effects of child physical abuse and preventing recurrence).$^{52} 5556$ Churches, schools and shelters, which would otherwise be safe havens, may be closed and healthcare facilities may be the option of last report. Bringing a child into a potentially hazardous hospital environment with the risks of nosocomial infection brings up difficult choices.

\section{IMPACT ON TRAINING}

Surgical training programmes are an additional casualty of the social distancing measures and surgical rationing. The reduction in elective surgical cases and clinics, as well as contact between teachers and trainees, has brought challenges in the delivery of surgical education worldwide. ${ }^{57-59}$ Academic training programmes have had to adapt rapidly to maintain the integrity of training programmes, ensure trainee welfare and comply with local laws. Postgraduate qualifying examinations of the West $^{60}$ and South African ${ }^{61}$ colleges of surgeons scheduled for April and July, respectively, have been postponed; however, the examination of the College of Surgeons of East, Central and Southern Africa (COSECSA) scheduled for November have not yet been impacted.

A recent global review of paediatric surgical workforce density showed that a minimum of four paediatric surgeons per million children under 15 years of age would be required to achieve a survival of $>80 \%$ for a group of four bellwether paediatric surgical conditions. ${ }^{62}$ This translates to a deficit of 6967 additional paediatric surgeons in LMICs required to attend to the almost 1742 billion children living there ${ }^{62}$ The paediatric surgical workforce deficit in Africa is particularly large, ${ }^{63}$ and disruption of training programmes is likely to significantly affect achievement of workforce goals.

The pandemic has also presented opportunities for surgical education. Virtual didactics are poised to increase the size of the classroom and to allow easier collaborative learning between teams in different hospitals or countries. This is occurring all over the continent and the practice may persist long after the pandemic is over.

\section{CONCLUSIONS}

The inexorable spread of COVID-19 around the world continues unabated and threatens to affect every clinical specialty. Children have unique needs and suffer disproportionately during health emergencies and therefore require enhanced protection. Paediatric surgeons in Africa have an important role during times such as these and should use tailor-made, context-appropriate strategies to minimise the impact on our patients and HCWs. Protection for HCWs should be the foremost in the minds of policy-makers as they are a precious and irreplaceable resource. 
Twitter Adesoji 0 Ademuyiwa @soji_ademuyiwa

Contributors All authors contributed to planning, conducting and reporting the work.

Funding The authors have not declared a specific grant for this research from any funding agency in the public, commercial or not-for-profit sectors.

Competing interests None declared.

Patient consent for publication Not required.

Provenance and peer review Not commissioned; internally peer reviewed.

Data availability statement There are no data in this work.

Open access This is an open access article distributed in accordance with the Creative Commons Attribution 4.0 Unported (CC BY 4.0) license, which permits others to copy, redistribute, remix, transform and build upon this work for any purpose, provided the original work is properly cited, a link to the licence is given, and indication of whether changes were made. See: https://creativecommons.org/ licenses/by/4.0\%.

ORCID iD

Dennis Mazingi http://orcid.org/0000-0001-8217-4642

\section{REFERENCES}

1 Martinez-Alvarez M, Jarde A, Usuf E, et al. COVID-19 pandemic in West Africa. Lancet Glob Health 2020;8:e631-2.

2 Li Q, Guan X, Wu P, et al. Early transmission dynamics in Wuhan, China, of novel coronavirus-infected pneumonia. N Engl J Med 2020;382:1199-207.

3 Nkengasong JN, Mankoula W. Looming threat of COVID-19 infection in Africa: act collectively, and fast. The Lancet 2020;395:841-2.

4 Vanderpuye V, Elhassan MMA, Simonds H. Preparedness for COVID-19 in the oncology community in Africa. Lancet Oncol 2020;21:621-2.

5 Ma X, Vervoort D. Critical care capacity during the COVID-19 pandemic: global availability of intensive care beds. J Crit Care 2020;58:96-7.

6 Dyer O. Covid-19: Africa records over 10000 cases as lockdowns take hold. BMJ 2020;369:m1439.

7 Outbreak Brief \#19: Coronavirus Disease 2019 (COVID-19) Pandemic, 2020. Available: file:///C:/Users/A/Downloads/AfricaCDC COVIDBrief_26MAY20_EN.pdf [Accessed 27 May 2020].

8 Xie Z. Pay attention to SARS-CoV-2 infection in children. Pediatr Investig 2020;4:1-4.

9 Wu Z, McGoogan JM. Characteristics of and important lessons from the coronavirus disease 2019 (COVID-19) outbreak in China: summary of a report of 72314 cases from the Chinese center for disease control and prevention. JAMA 2020;323:1239-42.

10 Castagnoli R, Votto M, Licari A, et al. Severe acute respiratory syndrome coronavirus 2 (SARS-CoV-2) infection in children and adolescents: a systematic review. JAMA Pediatr 2020. doi:10.1001/ jamapediatrics.2020.1467. [Epub ahead of print: 22 Apr 2020].

11 Dong Y, Mo X, Hu Y, et al. Epidemiology of COVID-19 among children in China. Pediatrics 2020;145:e20200702.

12 United Nations. World population prospects 2019: highlights. New York: United Nations, Department of Economic and Social Affairs, Population Division, 2019. https://population.un.org/wpp/ Publications/Files/WPP2019_Highlights.pdf

13 Ademuyiwa AO, Bekele A, Berhea AB, et al. COVID-19 preparedness within the surgical, obstetric and anesthetic ecosystem in sub Saharan Africa. Ann Surg 2020. doi:10.1097/ SLA.0000000000003964. [Epub ahead of print: 13 Apr 2020].

14 Leva E, Morandi A, Sartori A, et al. Correspondence from northern Italy about our experience with COVID-19. J Pediatr Surg 2020;55:985-6.

15 Davenport M, Pakarinen MP, Tam P, et al. From the editors: the COVID-19 crisis and its implications for pediatric surgeons. J Pediatr Surg 2020;55:785-8.

16 Collaborative C, COVIDSurg Collaborative. Global guidance for surgical care during the COVID-19 pandemic. Br J Surg;23.

17 Meara JG, Leather AJM, Hagander L, et al. Global surgery 2030: evidence and solutions for achieving health, welfare, and economic development. The Lancet 2015;386:569-624.

18 Gona CV. Letter to the editor: cancellation of elective surgery during the COVID-19 pandemic. East and Central African Journal of Surgery $2020 ; 25$.
19 SSZ COVID-19 Subcommittee. Statement on the conduct of surgical services during the COVID-19 outbreak, 2020.

20 ASSA Executive Council. Association of surgeons of south africa's statement on covid-19, 2020. Available: http://www.surgeon.co.za/ wp-content/uploads/2020/03/ASSAletterCOVID.pdf [Accessed 30 Apr 2020].

21 Surgical Society of Kenya Council. COVID-19: SSK statement on recommendations for surgical procedures and outpatient clinics, 2020. Available: https://www.ssk.or.ke/wp-content/uploads/2020/03/ SSK-covid-19-statement.pdf [Accessed 30 Apr 2020].

22 Schull MJ, Stukel TA, Vermeulen MJ, et al. Effect of widespread restrictions on the use of hospital services during an outbreak of severe acute respiratory syndrome. CMAJ 2007;176:1827-32.

23 Nepogodiev D, Bhangu A. Elective surgery cancellations due to the COVID-19 pandemic: global predictive modelling to inform surgical recovery plans. BJS.

24 Mason M. 'The NCEPOD Method' - How the National Confidential Enquiry into Patient Outcome and Death designs and delivers national clinical outcome review programmes. J Patient Saf Risk Manag 2018;23:35-45.

25 Pilkington M, Situma M, Winthrop A, et al. Quantifying delays and self-identified barriers to timely access to pediatric surgery at Mbarara regional referral Hospital, Uganda. J Pediatr Surg 2018;53:1073-9.

26 Kong VY, Sartorius B, Clarke DL. Acute appendicitis in the developing world is a morbid disease. Ann R Coll Surg Eng 2015;97:390-5

27 Knaapen M, van der Lee JH, Heij HA, et al. Clinical recovery in children with uncomplicated appendicitis undergoing non-operative treatment: secondary analysis of a prospective cohort study. Eur $J$ Pediatr 2019;178:235-42.

28 Chen $\mathrm{Y}$, Peng $\mathrm{H}$, Wang L, et al. Infants born to mothers with a new coronavirus (COVID-19). Front Pediatr 2020;8.

29 Fan C, Lei D, Fang C, et al. Perinatal Transmission of COVID-19 Associated SARS-CoV-2: Should We Worry? Clin Infect Dis.

30 Karimi-Zarchi M, Neamatzadeh H, Dastgheib SA, et al. Vertical transmission of coronavirus disease 19 (COVID-19) from infected pregnant mothers to neonates: a review. Fetal Pediatr Pathol 2020;0:1-5.

31 Shek CC, Ng PC, Fung GPG, et al. Infants born to mothers with severe acute respiratory syndrome. Pediatrics 2003;112:e254.

32 Jeong SY, Sung SI, Sung JH, et al. Mers-Cov infection in a pregnant woman in Korea. J Korean Med Sci 2017;32:1717-20.

33 Wang S, Guo L, Chen L, et al. A case report of neonatal 2019 coronavirus disease in China. Clin Infect Dis;348.

$34 \mathrm{Xu} \mathrm{Y,} \mathrm{Li} \mathrm{X,} \mathrm{Zhu} \mathrm{B,} \mathrm{et} \mathrm{al.} \mathrm{Characteristics} \mathrm{of} \mathrm{pediatric} \mathrm{SARS-CoV-2}$ infection and potential evidence for persistent fecal viral shedding. Nat Med 2020;26:502-5.

35 Coccolini F, Tartaglia D, Puglisi A, et al. SARS-CoV-2 is present in peritoneal fluid in COVID-19 patients. Annals of Surgery.

36 Bundu I, Patel A, Mansaray A, et al. Surgery in the time of Ebola: how events impacted on a single surgical institution in Sierra Leone. J R Army Med Corps 2016;162:212-6.

37 Ho SMY, Kwong-Lo RSY, Mak CWY, et al. Fear of severe acute respiratory syndrome (SARS) among health care workers. J Consult Clin Psychol 2005;73:344-9.

38 Abolfotouh MA, AIQarni AA, Al-Ghamdi SM, et al. An assessment of the level of concern among hospital-based health-care workers regarding MERS outbreaks in Saudi Arabia. BMC Infect Dis 2017;17:4.

39 Elston JWT, Cartwright C, Ndumbi P, et al. The health impact of the 2014-15 Ebola outbreak. Public Health 2017;143:60-70.

40 Hagopian A, Zuyderduin A, Kyobutungi N, et al. Job satisfaction and morale in the Ugandan health workforce. Health Aff 2009;28:w863-75.

41 Campbell J, Dussault G, Buchan J, et al. A universal truth: no health without a workforce. Geneva: Global Health Workforce Alliance and World Health Organization, 2013. https://www.who.int/ workforcealliance/knowledge/resources/GHWA-a_universal_truth_ report.pdf

42 Kelvin AA, Halperin S. COVID-19 in children: the link in the transmission chain. Lancet Infect Dis 2020;20:633-4.

43 Basu L, Frescas R, Kiwelu H. Patient guardians as an instrument for person centered care. Global Health 2014;10:33.

44 Makworo D, Bwibo N, Omoni G. Parental involvement in the management of hospitalised children in Kenya: policy and practice. Afr J Midwifery Womens Health 2014;8:183-8.

45 Hoffman M, Mofolo I, Salima C, et al. Utilization of family members to provide hospital care in Malawi: the role of hospital guardians. Malawi Med J 2012;24:74-8. 
46 Mukhopadhyay A, Tambyah PA, Singh KS, et al. Sars in a hospital visitor and her intensivist. J Hosp Infect 2004;56:249-50.

47 Gopalakrishna G, Choo P, Leo YS, et al. Sars transmission and hospital containment. Emerg Infect Dis 2004;10:395-400.

48 Tan TK. How severe acute respiratory syndrome (SARS) affected the Department of anaesthesia at Singapore General Hospital. Anaesth Intensive Care 2004;32:394-400.

49 Munoz-Price LS, Banach DB, Bearman G, et al. Isolation precautions for visitors. Infect Control Hosp Epidemiol 2015;36:747-58.

50 Rosenthal DM, Ucci M, Heys M, et al. Impacts of COVID-19 on vulnerable children in temporary accommodation in the UK. Lancet Public Health 2020;5:e241-2.

51 Dunn CG, Kenney E, Fleischhacker SE, et al. Feeding lowincome children during the Covid-19 pandemic. N Engl J Med 2020;382:e40.

52 Magoteaux S, Gilbert M, Langlais CS, et al. Should children with suspected Nonaccidental injury be admitted to a surgical service? J Am Coll Surg 2016;222:838-43.

53 Campbell AM. An increasing risk of family violence during the Covid-19 pandemic: strengthening community collaborations to save lives. Forensic Science International: Reports 2020;2:100089.

54 Barret JP, Chong SJ, Depetris N, et al. Burn center function during the COVID-19 pandemic: an international multi-center report of strategy and experience. Burns 2020. doi:10.1016/j. burns.2020.04.003. [Epub ahead of print: 10 Apr 2020].

55 Escobar MA, Wallenstein KG, Christison-Lagay ER, et al. Child abuse and the pediatric surgeon: a position statement from the trauma Committee, the Board of governors and the membership of the American pediatric surgical association. J Pediatr Surg 2019;54:1277-85
56 Scott D, Lonne B, Higgins D. Public health models for preventing child maltreatment: applications from the field of injury prevention. Trauma Violence Abuse 2016;17:408-19.

57 Coe TM, Jogerst KM, Sell NM, et al. Practical techniques to adapt surgical resident education to the COVID-19 era. Ann Surg 2020. doi:10.1097/SLA.0000000000003993. [Epub ahead of print: $29 \mathrm{Apr}$ 2020].

58 Bryan DS, Benjamin AJ, Schneider AB, et al. Nimble, together: a training program's response to the COVID-19 pandemic. Ann Surg 2020. doi:10.1097/SLA.0000000000003994. [Epub ahead of print: 29 Apr 2020].

59 Calhoun KE, Yale LA, Whipple ME, et al. The impact of COVID-19 on medical student surgical education: implementing extreme pandemic response measures in a widely distributed surgical clerkship experience. Am J Surg 2020. doi:10.1016/j.amjsurg.2020.04.024. [Epub ahead of print: 28 Apr 2020].

60 Gueye S, Mshelbwala PM. Notice of postponement of West African College of surgeons (WACS) April 2020 examinations, 2020. Available: https://www.wacscoac.org/ [Accessed 10 May 2020].

61 Senkubuge F. Announcement to CMSA candidates, 2020. Available: https://www.cmsa.co.za/force download.aspx?documentid= $7278524332383634383272785243 \&$ Name=Announcement $\%$ 20To\%20Candidates\%201st\%20Semester\%20and\%202nd\% 20Semester\%202020\%20exam [Accessed 30 Apr 2020].

62 Hamad D, Yousef Y, Caminsky NG, et al. Defining the critical pediatric surgical workforce density for improving surgical outcomes: a global study. J Pediatr Surg 2020;55:493-512.

63 Krishnaswami S, Nwomeh BC, Ameh EA. The pediatric surgery workforce in low- and middle-income countries: problems and priorities. Semin Pediatr Surg 2016;25:32-42. 